\title{
REPRESENTATION OF TURKEY IN THE NEWS ON THE CYPRUS PROBLEM: AN ANALYSIS ON THE BRITISH PRESS (2000)
}

\author{
KIBRIS SORUNUNA İLISŞKIIN HABERLERDE TÜRKIYYE'NIN TEMSIILİ: İNGIILIZZ BASINI \\ ÜZERIINE BIIR İNCELEME (2000)
}

\section{Hanife ERIŞSEN ${ }^{a}$ \\ Nilüfer TÜRKSOY ${ }^{b}$}

Doi: 10.53281/kritik.988133

${ }^{a}$ Araştırma Görevlisi, Doğu Akdeniz Üniversitesi, Iletişsim Fakültesi, 0000-0001-8830-8664, b Doktor Öğretim Üyesi, Doğu Akdeniz Üniversitesi, İletişsim Fakültesi, 0000-0002-1075-5031

\section{MAKALE BÍLGILERİ}

\section{Makale:}

Gönderim Tarihi: 28.08.2021

Ön Değerlendirme: 11.09.2021

Kabul Tarihi: 14.12.2021

\section{Anahtar Kelimeler: \\ İngiliz basını; Kıbrıs sorunu, medya temsili; Türkiye, ötekileştirme; oryantalizm, Said.}

\author{
Key Words: \\ British press; Cyprus problem; media \\ representation; Turkey; othering; \\ orientalism; Said.
}

\begin{abstract}
ÖZET
Bu çalışma, 2000'li yıllarda Kıbrıs sorununu ele alan İngiliz haber metinlerinde Türkiye'nin temsilini araştırmayı amaçlamaktadır. Makale, Kıbrıs'ın kaderinde rol oynayan devletlerden biri olarak İngiltere basınının Türkiye'yi nasıl temsil ettiğini sorgulamaktadır. Değerlendirme için Said'in Oryantalizm ve Young'ın Beyaz Mitoloji kuramlarından yararlanılarak, 45 haber metni üzerinden nitel içerik analizi yapılmıştır. Bulgular, bu dönemde Türklerin ötekileştirildiğini ortaya koymaktadır. İngiliz basını Kıbrıs sorununa karışan Türkleri "koyu tenli", "az gelişmiş Doğu Anadolu'lu", "İslami kıyafet giyen ve geniş aileleri olan", ve Kıbrıs adasında "yerleşikler" veya "işgalciler" olarak tasvir etmektedir. Kıbrıs sorununa ilişkin diğer rol oyuncularının (Yunanistan, Kıbrıslı Rumlar ve Kıbrıslı Türkler) ise nispeten daha az sıklıkta ötekileştirildikleri gözlemlenmiştir.
\end{abstract}

\begin{abstract}
This study aims to explore the representation of Turkey in the British news texts covering the Cyprus problem in the 2000s. The article goes on to question how the British broadsheet press represents Turkey, as one of the role-playing states in the fate of Cyprus. Using Said's Orientalism and Young's White Mythology as a theoretical basis for evaluation, a qualitative content analysis was utilized upon 45 news texts. Findings established that the othering of Turks was alive during this period. The British press portrayed Turkish people involved in the Cyprus problem as 'dark-skinned Turks', 'from underdeveloped eastern Anatolia' that 'wear Islamic dress and have large families' and are 'settlers' invaders or occupiers on the Cyprus island. Comparatively, the other role-players in the Cyprus problem (Greece, Greek Cypriots, and Turkish Cypriots) were less frequently Orientalized and not in the traditional sense, as presented by Said, their level of being orientalized relating to their relations with the British.
\end{abstract}

(C) 2021- e-ISSN 2667-6850 


\section{INTRODUCTION}

Jacques Derrida presented to the world that words/concepts contain positive and negative meanings. This relationship that is known as binary oppositions maintains an infinite privileged status to one of the terms. In history, the western way of thinking is established upon this logic (Pinkus 1996). Westerners utilize this relationship to define their identity as the "self", always privileged in this hierarchal positioning, while appropriating their opposite as the "other" (Paksoy 2012; Kösebalaban 2007). Burr (1995: 73), for example, emphasizes "To give anything an identity, to say what it is, is necessarily also to say what it is not. In this sense, presence contains absence. That is, to say that a quality is present depends upon implying what is also absent". Based on this notion, Edward Said (2003) founded orientalism, which at the most general level, is a style of thought based upon the basic distinction made between the Orient and the Occident, or the East and the West. Orientalism asserts the existence of the Eurocentric or, in this case, the Anglocentric ideology, taking the white western male as central, and subjecting all else as the Other. As highlighted by Said (2003: 3), the West essentialized Eastern societies as static and under-developed: "Implicit in this idea is that Western society is developed, rational, flexible and superior". Western societies were able to achieve such an understanding by actively teaching, describing, or making statements about the Orient, and by authorizing views over it, by settling and ruling over it (Said 2003). Here, Said indicates that discourse is power, and in this ever-changing world; it appears to be an ideology the westerners have invested and re-invested in for decades, as for the self to exist, it requires the other (see also Lévi-Strauss 1963). "Historically, a combination of (mis)information has worked to construct an enemy image in the popular imagination that has an important function in the maintenance of political power, or hegemony, through ideology" (Merskin 2004: 158).

Similar to orientalism, white mythology is a theory based on the self-other binary relationship, and another method utilized by the western world to infiltrate their ideologies to the rest of the world. According to Young (1990), white mythology is the implementation of the western ideology, for the production of white-washed versions of developments in history, essentially putting a Eurocentric spin on history, to produce a version that centres around the white-Western-male. A sister theory of orientalism, Young (1990), quotes Said in his description of white mythology, presenting the objective as "to develop an epistemological critique of the West's greatest myth - History" (Young 1990: 2). Such work has made a significant contribution to our understanding of the contested relationship between the 
"self" and the "other".

Inspired by these remarks, this article will provide insights into how foreign others are represented in British daily newspapers, made more significant when the Cyprus problem is concerned. The Cyprus problem is a long-standing conflict between two ethnic communities: the Turkish and Greek Cypriots, and as the literature has previously indicated and crucial to this study, a conflict between the self and the other, upon a small Mediterranean Island. In particular, the study aims to understand the complexity of the representation of the Turkish identity among and in comparison, to the other role-playing identities within the Cyprus problem. Given Turkey is one of the role-playing states in the fate of Cyprus and has required political control over the northern part of Cyprus, to ensure the safety of the Turkish Cypriot population (Bartlett 2013), as it is claimed, or as another land to conquer and rule over, as some may argue, it's a case par excellence to evaluate how the British press represents Turkey as a second signatory to the Treaty of Guarantee; a treaty between Cyprus, Turkey, Greece, and the United Kingdom. The representation of the Turkish identity has additionally been taken to hand with relation to the Cyprus problem, as there is very little prior data in relation to the representation of the Turkish Cypriots in western media and thus, a unique handling can be grasped with relation to understanding whether an identity that is known to be orientalised, maintains this form of orientalisation in relation to such a sensitive political issue and whether there is any form of orientalising present within discussions surrounding the Cyprus problem. This study is further interested in deciphering the representation of Turkey in relation to the Cyprus issue, to evaluate the representation of the Turkish identity in connection to other matters or issues, external to any immediate issues concerning Turkey, where they play a side role. A majority of previous literature takes on board the representation of the other directly and rarely have studies engaged in exploring whether such representations continue on issues that are not directly related to that identity. As such in this case, do the journalists continue the same representations in matters where Turkey and its people are not the main focus? Further, this study is also an opportunity to grasp how a known representation of such an identity stands in comparison to other identities regarded within the realms of the self in this binary relationship, where such representations in relation to such a sensitive political situation may affect the political direction of this matter. Taking to hand the period from the 2004 Kofi Annan Peace Plan Referendum (the Basis for Agreement on a Comprehensive Settlement of the Cyprus Problem) and five years prior (2004 -1999), the present study aims to uncover the prevailing discourses and use of language in the British press concerning Turkey and its people. The study also sheds some light on the representation of the other role-playing identities, providing an understanding of how the British press evaluated and thus represented all those involved in the Cyprus problem. This 
period was selected because the efforts to solve the Cyprus problem intensified and media coverage of the problem increased simultaneously at that time, hence the increased amount of directly related news articles within a certain period, providing the ideal opportunity for analysis. The representation of Turkey is taken into the hand with the focus of the self and other lens and additionally compared with the other identities involved.

The academic literature provides sufficient evidence suggesting that Turkish people have often been subjected to orientalist ideology and narratives and are widely represented as the Other in western writings (see Birce 2015; Wimmel 2009; Negrine et al. 2008; Bryce 2007; Devran 2007; Aissaoui 2007; Spyrou 2002). Their Islamic faith, for instance, is already known to be subjected to negative coverage in the western news media (Douai and Lauricella 2014). Neumann (1999), as well as Kylstad (2010: 7), argues that "Turkey has historically been Europe's significant Other due to its military might, physical proximity and a strong religious, rivalling tradition". Devran (2007), also documented that history plays a pivotal role in the othering of this nationality, as their Ottoman heritage and the negative feelings towards this former empire are inherited in today's western media's representations of the Turks. Aissaoui (2007: 7), similarly, argues that "Turkey has a poor image in the unconscious of Europeans, including in countries that did not suffer under the Ottoman past of the Turks". Gangloff (2008), highlighted that Turkey is often presented and perceived as an oriental and backward country, beyond the borders of Europe, and is foreign in many aspects to the European spirit. This often-derogatory perception of Turkey and its people helps the western readers to easily grasp the difference between the East and the West, or the difference of Turkey from the west. Today, these mainstream political discourses about Turkey find substantial coverage in the western news media. The current study is an attempt to evaluate whether this form of discourse was present between 1999 and 2004 in the British news texts covering the Cyprus problem, a political matter not directly related to Turkey. Given the Cyprus problem additionally concerns Greece, the Greek Cypriots, and Turkish Cypriots, this case equally provides an opportunity to compare the way Turkey and other role-players are represented.

Turkey, Greece, and the United Kingdom, which have been present and dominant within the Mediterranean for some centuries, have also been active in the Cypriot strife, where it can be posed that their presence with relation to this Mediterranean Island is in light of their conflicting agendas, (Bartlett 2013) where Turkey and Greece historically have wanted to maintain rule over the island, and the United Kingdom has just wanted to maintain their presence. These three powers have played integral roles in the plight of Cyprus and the Cypriots. Following the colonization by the British Empire in 1914, life on 
the island began to change (French 2016; Varnava 2009; Kliot and Mansfield 1997) due to the increasingly souring relations between the Greek and Turkish Cypriots, mirroring the centuries old difficult relations between Greece and Turkey, the ancestors of the Cypriots. The difficult relations between the once harmonious communities resulted in furthering segregation by the establishment of EOKA (Ethniki Organosis Kibrion Agonisdon, translated as National Organisation of Cypriot Struggle) a movement fighting for Enosis (connecting Cyprus to Greece), retaliated by the Turkish Cypriots calling for TAKSIM (partition). A long period of unrest was experienced on the island, with a civil war in 19521954 (Kliot and Mansfield, 1997), Greek Cypriot Lieutenant Colonel and leader of EOKA; Georgios Grivas, struck out during the early hours on the 1st of April 1955 with attacks against the Turkish Cypriots, beginning a concerted effort for enosis, affecting both the Greek and Turkish communities, as well as the British authorities present (French, 2016). This was the initial introduction of EOKA on the island (Göktürk, 2018). While peace talks ensued on the island, so did the unrest: in 1958, March witnessed EOKA attacks upon British targets, and in June, attacks by Turkish Cypriots on Greek Cypriots, with Greek Cypriot retaliation soon following. October witnessed a major campaign of force by EOKA, against the British authorities on the island (Xydis, 1973: 10), with all of these developments forcing Turkish Cypriots into enclaves. There was to be no respite when the Republic of Cyprus was established between the two communities in 1960. The post-colonization political and socio-economic difficulties support the claims of Young (1990) and his coining of the word; in-dependence, describing the economic and political dependence of countries from their previous colonizers, following their gaining of independence. This terminology has proved appropriate in describing and understanding the backstory to Cyprus' conundrums. Following many years of unrest, with both communities involved in performing atrocities, one of the final blows to the island was a Greek military junta in July 1974, which saw the bloodshed of Greek and Turkish Cypriots alike. Guarantor Turkey, following consultation with the United Kingdom, intervened for some and invaded for others, and subsequently divided the island (Göktürk 2018). Greek Cypriots fled to the South of Cyprus in forced migration, and all the Turkish Cypriots moved to the north of the island, the forced migration resulted in leaving property and belongings, and even loved ones. In 1983, the Turkish Cypriot leadership declared the de facto Turkish Republic of Northern Cyprus (TRNC), established on the territory accepted as part of the internationally recognized Republic of Cyprus (RoC), administered by Greek Cypriots since 1963. "The RoC considers the territories controlled by the TRNC under occupation and claims a full sovereignty over all the island" (Akçalı 2011: 1730), a sentiment shared by the international community and law. The actions of Turkey are deemed as illegal occupation of the internationally recognized $\mathrm{RoC}$, which has led to the continued plight of the Greek Cypriots being unable to return to their lands and properties and the Turkish Cypriots existing unrecognized by the world but Turkey, residing illegally on what is accepted as occupied 
territory. For many Turkish Cypriots however, it is home, and Turkey saved them from genocide when the rest of the world turned their backs. In North Cyprus, many Turkish Cypriots stand politically divided, weary from the international isolation history has bestowed upon them. While a large section of the society blames Turkey for their current standing, viewing it as another form of colonisation, the other half view that the only other solution; peace with the Greek Cypriots, ultimately means submittance to the enemy, calling that the Greek Cypriots have done it once, they will do it again. Such narratives are prevalent within the Turkish Cypriot media discourses, establishing imagined communities of Turkishness as Cypriotness (Ciraki, 2018), essentially creating a divide within a divide.

Today, some 46 years later and separated by a buffer zone, Cyprus exists with two distinct and separate communities remaining segregated: the Turkish Cypriots (TC) to the north and the Greek Cypriots (GC) to the south, with the political status upon the island remaining as in ceasefire. Not all are equal, however, with the Greek Cypriots maintaining an internationally recognized status and joined the European Union (EU) in 2004. The Turkish Cypriots to the north exist with an internationally unrecognized government with political, economic, and at times, socio-cultural embargoes, and sanctions by the world. "Turkey is the only state in the world that recognizes the TRNC and that does not recognize the RoC" (Akçal1, 2011: 1730). This situation has increased the TC's military and economic dependence on Turkey, giving Turkey control over North Cyprus's internal affairs. As a result of the tumultuous history, while Turkey claims an intervention in 1974 to save the Turkish Cypriots when no one else was, a recount echoed by many Turkish Cypriots, the Greek Cypriots alongside the world view this development as an illegal invasion that forced migration of the Greek Cypriots, leading to unimaginable material losses and sentimental connections to home. As it is clear, narratives continue on each side of the Green Line, not helped by the 'motherland nationalism' deriving from primary loyalty to Greece and Turkey "mainlands" and identifying as Greek and Turkish (Psaltis and Chakal, 2016).

This study is limited by several factors. First, the study focuses on the representation of the British press only about the Turkish identity, and in connection to the Cyprus problem. Therefore, generalisations cannot be made beyond this area of study in connection to other subjects or the press of other nations. As the study focused upon the representation of the Turkish identity on the subject of the Cyprus problem, only 45 articles were produced that were directly related to the Cyprus problem and not the many other developments during this time. Another limitation is in relation to the time period, between 1999-2004. Assumptions about the representation of the Turkish identity cannot be made beyond this point. 
Primarily relying on the theoretical work of Said's Orientalism (2003) and Young's (1990) White Mythology, and by applying a qualitative content analysis (Schreier 2012) upon 45 news articles that take the Cyprus problem to hand as the core subject, and are published across five British broadsheet newspapers (The Guardian, The Times, The Sunday Times, The Independent, and The Daily Telegraph), this study aims to uncover the following two questions:

RQ1: How is Turkey represented in the news content of British daily newspapers covering the Cyprus problem from 1999-2004?

RQ2: What kind of language is dominant in portraying the Turkish people politically, economically, and culturally, in the selected period?

Before explaining the method and data used, we will devote some time to reviewing the literature that is relevant to theories of the media representation of Others, with a particular emphasis on the orientalism discourse in foreign affairs reporting.

\section{Orientalism and Othering in the Western Media}

Binary oppositions are a logic settled into the minds of language users, instantly placing the self and the other in their places, and immediately making connections with the framed images and connotations they maintain (Fourie 2001; Saussure 2011). Like a norm, unquestioned by its communicators, this relationship between the words we utter and the thoughts and realities they form continue, invested in every time the words are spoken by an individual, written in a schoolbook or newspaper, mentioned on the television, and suggested in art forms. It is at this point that ideology connects with communication and thus, language, and it is in this way that the west was able to interweave their ideologies into the words we speak and disseminate it, in every form of communication.

Journalistic efforts play a large role in the formation of dominant opinions within a society and the understanding and mediation of reality (Fowler, 1991). A recent study looking at journalism in Cyprus acknowledges that journalists and editors "make decisions about what to report and how to report it” (Şahin and Karayianni 2020: 1361). Besides shaping the news, journalists' "judgments, decisions and 
actions are the key elements in the news production process" (Şahin and Karayianni 2020: 1362). In Northern Cyprus, it has been observed that Turkish Cypriot Media output reflects mainstream narratives (Cirakli, 2018). Moreover, "the closer the reporters/editors are to a given news event in terms of national interest, the further they are from applying professional news values" (Nossek 2004: 343). The language they use can affect how the readership reacts to news (McNair, 2009). Journalists have the power to select certain events or information and to leave out others and publish them in the form of stories known as editorials or leading articles, that the public recognizes as news (Manoff and Schudson 1986; Gans 1979). Of course, it can be argued that there are a plethora of ways to tell a story, but in the case of journalists, they are not accidental, with Schudson (2003) fundamentally reminding us that journalists create reality and make waves. Schudson (2003: 33) highlights that "News is not a mirror of reality. It is a representation of the world, and all representations are selective". "Media are mobile spotlights, not passive mirrors of society; selectivity is the instrument of their action. A news story adopts a certain frame and rejects or downplays discrepant material. A story is a choice, a way of seeing an event that also amounts to a way of screening from sight" (Gitlin 1980: 49-51). Once the realities imparted to the readership are taken on board by society, and the journalists' narratives become that of the readers' narratives, through the consent of those readers, spoken language can create boundaries, form hierarchies, shape realities, and support power relations all in context of the political, economic, power institutions and elites present within a society (Van Dijk 1991). With such power bestowed upon the press, it is no wonder that the wording, visuals, content, setup, and ideologies of newspapers are frequently scrutinized and evaluated (Schudson 2003; Van Dijk, 1991). Chomsky and Edward (1988), for instance, claim that in the case of foreign reporting, press objectivity weakened. In a similar vein, Herman and Chomsky (2002) claim that journalists are willing to give up professional norms to national interests. Journalists' behaviour, thus, is context-dependent (Nossek 2004).

Orientalism has continually been woven into news texts (Jackson 1996; Merskin 2004; Birce 2015; Paksoy 2012; Devran 2007). It involves stereotyping the concept of the "Orient" as "other", which has remained more or less unchanged till today (see Spyrou 2002; Merskin 2001; Hall 1997). The study of Merskin (2004), for instance, has shown that despite cultural and visual differences, geography, background, and levels of education, all Muslims, Arabs, and those residing particularly in the Middle East have been stereotyped; they are Orientalized and characterized as the Other. Such stereotypes that "tend to lump Arabs, Muslim, Middle East into one highly negative image of violence and danger" (Jackson 1996: 65) tend to be the creation of collective memory, as opposed to real experience. These orientalist efforts, stereotyping the Other, simultaneously have reinforced the structures of the western 
identity. The study of Bakić-Hayden which looks at how eastern Europe in general, and Former Yugoslavia in particular, has been represented by the westerners, outlines that eastern Europe is perceived as less European. It "has been commonly associated with "backwardness," the Balkans with "violence," India with "idealism" or "mysticism," while the west has identified itself consistently with the "civilized world" (1995: 917).

Bordering Eastern Europe, Turkey has been awarded no exceptions. Persistency of othering was observed in the case of the British press. Devran (2007) analysed that whenever Turkey is mentioned within British news texts, space is often given to highlight their Islamic identity. Devran (2007: 103) concludes that "whoever reads the British newspapers will face various descriptions of Turkey as a poor, predominantly Muslim, culturally alien, over-crowded country, with a population of 72 million; a country with a shaky democracy and economy that lies geographically outside the boundaries of Europe". Paksoy (2012), similarly, acknowledges that any adjectives, words, reductionist terms, and phrases utilized by the British press in the description of Turkey, generally associated with a religious difference, a Muslim label. One fact of such representations is that "British cultural tradition contains elements of derogatory to foreigners" (Schudson, 2003: 173).

Especially, after September 11, 2001, the World Trade Centre attacks in New York, studies confirmed that the western media's othering of the Islamic faith had dramatically increased, with the most common adjectives used when referring to Muslims being radical, fanatical, fundamentalist, and extremist, or militant (Poole 2002). This stereotypical language dominates the British media, resulting in the audience having a limited understanding of the faith and its followers, and the preferred reading or meaning of this discourse only inferring the otherness of the Muslims (Birce 2015). Poole's (2002) book exploring the media representation of British Muslims and reporting of Islam, acknowledges that the orientalist discourse and constructions of the other continue to be manifested similarly. Comparable findings drawing on the negativity of Islam and Muslims are found in Poole and Richardson's (2006) book too. From a critical appraisal, the authors acknowledge that the binary oppositions of us and them are repacked in news discourse and conclude that mainstream western media tend to represent Islam with a limited repertoire characterizing negativity. Muslims are stereotyped as being misogynistic, intolerant, and violent/cruel, or strange/different (Poole and Richardson 2006). Saeed's (2007) review of the literature equally acknowledges that western media is overtly biased and xenophobic, and the tone of the rhetoric is often alarmist. Islam, which the majority of the Turkish people identify as, is regarded as a medievally backward religion, symbolizing terror, and discourse has been produced that links Muslims 
with support for terrorism, fundamentalism, or illegal immigration. Bail's (2015) study concluded that any negative messages about Muslims received a higher level of media attention than their positive opposite in the western world.

Another ideology noted to be laced within discourse and media, is Young's (1990) white mythology. With white mythology, Young (1990) has directly challenged the European Marxist claim to a totalizing knowledge, a knowledge that is acknowledged as being eternal, presented in an objective nature, forming the grounding of a dialectical theory of history in perspective, but essentially an effort that functions fully in the realms that are fundamentally a European only perspective (cf. Spivak 2009; Said 2003). Like orientalism, it is accepted that white mythology has been made possible by utilizing language as a vehicle to deliver this ideology, enhancing the superior idea of the west. As modernist notions of development, progress, and history are a portrayal of the first world, this in turn has reserved them the right to theorize about history and humanity. The words history and humanity indicate that this right is for men only, and not for women and the third world. This is because "History with a capital " $\mathrm{H}$ " cannot tolerate otherness or leave it outside its economy of inclusion. The appropriation of the other as a form of knowledge within a totalizing system can thus be set alongside the history of the European imperialism" (Young 1990: 35). As recounted by Cixous, a commonplace presentation of history is that there must always be two races in existence, the masters, and the slaves (in Spivak 2009). Thus, white mythology outlines that this European ideology has dominated historical output, by omitting true events, to present the European perspective only. In the western version of history, the others, the colonized, the subalterns' existence is not ignored for sure, as they play a pivotal role in propping and enhancing the identity of the west, in a binary relationship they find themselves within the self with their other, the masters with their slaves (Spivak 2009). The perspective of the other can rarely be stumbled upon, their existence within history is a mere convenience for the western need of self- definition. The colonizer's version told us that they took modernity, technology, democracy, development, and education to the colonized lands and people, what little versions of the colonised recounts have seeped through vastly differs from that of the colonised and speaks of pain and trauma. While historically white mythology would have been laced within artwork depicting preferred visualizations of events, novels outlining ideal narratives, and history books indicating tainted versions of reality, in the recent past and present time, such ideologies would be stumbled upon in modern media, television reports, websites, and news texts.

What is suggested is that foreign news coverage involves special national characteristics and symbols (Schudson 2003), which the journalists working for the British press maintain, in this case in relation to Turkey. Additionally, readers of that section are presumed to know little about that country. 
Our purpose, therefore, is to explore how the British foreign news texts produce meaning regarding Turkey when reporting on the Cyprus problem. In search of answers, we examine Turkey's portrayal in recent history. Before discussing the findings more comprehensively, we shall provide some information about the method and data.

\section{Materials and Methods}

For this empirical research, texts in the foreign or international news sections taking the Cyprus problem to hand as the core subject and published across five British newspapers were selected for analysis. Only broadsheet newspapers with different editorial profiles in the British media landscape were considered: The Guardian, the Independent, the Daily Telegraph, the Times, and its sister paper the Sunday Times.

The ProQuest Central search engine was utilized for this study. We apply three filters during the search to narrow down the results to deliver the desired field of study. The first filter applied was the 5 years' time frame; beginning from 24 April 1999 till 24 April 2004, the latter being the official date of the Kofi Annan Peace Plan referendum. The referendum is a significant development in the Cyprus issue timeline, as it is regarded as the day that the two communities officially confirmed their political stance. By delivering a "yes" vote for peace and reconciliation by 65 percent, the Turkish Cypriots officially proved their pro-reconciliation positions, while a "no" response was placed by the Greek Cypriots at a rate of 75 percent, proving their positions also (Sözen and Özersay 2007). These 5 years are chosen for two reasons: (1) it was a politically active time for all involved in the Cyprus problem, and (2) the Kofi Annan Peace Plan Referendum marked a pivotal moment in history for the Cyprus problem. The second filter applied was the selection of broadsheet newspapers, as they produce more serious reporting on politics, economic and foreign affairs, as opposed to tabloids or regional newspapers. The last filter applied was to search a specified subject, the "Cyprus issue", including the specific keywords; "Cyprus Problem", "Turkey", and "Cyprus". This search delivered 304 articles in total. However, to locate the articles directly related to the Cyprus problem only, the abstracts of each of the 304 qualifying articles (format in which they are delivered from ProQuest), were carefully read to establish their true qualification. Due to the political activity at the time, the Cyprus issue was frequently referred to in passing in other articles relating to other subjects, such as Turkey's EU bid or the Greek Cypriot general elections. Such articles were not considered. It was found that out of the 304 articles, 45 were directly related to the Cyprus problem and Turkey (see Appendix I: List of news items used for analysis). 
The study employs a qualitative content analysis, a research method that helps us to focus specifically on language characteristics, contextual meaning of text data, and content (Schreier 2012). Qualitative content analysis is applied to subjectively interpret text data, by enabling the researcher to reliably and systematically analyse data of a qualitative nature, whereby generalizations can then be produced (Schreier 2012). Based on these assumptions, we examine the news texts by using two analytical tools: (1) the presence of orientalism, and (2) the investment in white mythology. We, first, focus on the main ideas and looked at the level of orientalism in terms of the information international news carry; then we analysed the content of each body of text with respect to popular adjectives used by British journalists to ascribe meaning to Turkey. In that same section, we looked at the forms of linguistic implementation, of language differences or similarities used by British journalists to represent the Turkish people; we also looked if Turkey is presented as part of the Orient and, if, or to what extent Turkish people are presented as Others? An additional focus was in relation to how the representation of Turkey compared to the other role players in the Cyprus problem. Secondly, we study the contents and look at what issues and ideas are stressed in terms of white mythology. This means that we looked at the texts to see if white mythology is circulated between the lines of the international news. In this section, we looked at how the texts are constructed, and what narratives are embedded within the articles, and crucially, what information is missing and whether equal space is given to each side of the story, factors that may impact the general understanding of events.

\section{Results}

\subsection{The Presence of Orientalism}

The results suggest that the British broadsheet newspapers' representation of each of the role holders coincided with their level of inconveniencing the British agenda in Cyprus, a situation which becomes more apparent with the forms of representations upon the other identities and the timing/subject at hand. In this sense, the most highly Orientalized or "other" within the representations was Turkey, accepted as most challenging the British agenda upon the island, with traditional forms of orientalism observed. The Daily Telegraph, for example, speculated in one article: "in their place, dark-skinned Turks from Anatolia and Kurds from South-eastern Turkey are moving in. At the far end of Niazi's street, a woman in an embroidered headscarf chases chickens back into her garden" (7 September 2002). Common derogatory adjectives, seen previously across literature and suggested by Said (2003), (e.g., “dark-skinned”, "headscarf”) were used to Orientalize the Turkish people living in the north of Cyprus. Such descriptive references referring to the colour of skin, for example, were not seen to be made in relation to the residents of the south of Cyprus. It is additionally questionable from an ethical perspective 
what the relevance of skin colour has in this matter. Nevertheless, it is already known that dark skin has negative connotations connected to it, with the Arabian descent of the Turks unforgotten which positioned them as a 'complicated' other, but still an 'other' (Birce, 2015). This representation has painted a picture that all the Turks that have come to Cyprus from Anatolia and the Kurds from Southeastern Turkey are dark-skinned, that they wear Islamic headscarves and are all Muslim, and they are likely to be raising animals, a more primitive form of people (chasing chickens), thus insinuating an education level. The picture, it can be argued, becomes direr when teamed up with occasional reference to the number of settlers who have come from Turkey to live in North Cyprus, presented as being half the 200,000 population. Here is another example of such traditional forms of othering, this time presented by the Sunday Times: "Denktash has encouraged mainland Turks to settle there [in Cyprus], most of them from underdeveloped eastern Anatolia. The women wear Islamic dress and have large families. Turkish Cypriots, who are mostly secular, have become a minority within their own "republic"" (17 November 2002). This excerpt indicates that settlers from Anatolia dress in Islamic attire, have large families and that this is not secular. They are from an underdeveloped location of the world, and that this location is in eastern Anatolia. It additionally defines fundamental differences between the Turk and the Turkish Cypriot, although in other examples we have seen them lumped together (Jackson, 1996) against the identity of the European self.

In another way of Orientalizing the Turks, those that had emigrated from mainland Turkey to live in the north of Cyprus were critically referred to as "settlers" by the British journalist covering the unrest. Take this example: "Lack of opportunities in the north has caused increased migration of young TurkishCypriots, who have been replaced, to some extent, by settlers from Turkey. They now account for nearly half the population, which is thought to be about 200,000. There are also 35,000 Turkish troops" (Times, 1 October 2002). By using the term "settlers", which already has negative connotations (Barthes 1961, Cirakli, 20181) associated with it, the British journalists have applied such negative connotations to the Turks from mainland Turkey. This finding harmonizes, with academic literature that also put forth that the Turks living in the north were "settlers" (cf. Navaro-Yashin, 2006). In terms of identity politics, and as outlined by Cirakli (2018: 199), "the presence of individuals of Turkish origin who have moved to Cyprus from Turkey since 1974" is seen as an important dimension of the Cyprus problem. This terminology used in the British broadsheet press, it can be put forth, mirrors the mainstream discourses and narratives that dominate the political field; in other words, to a certain degree, it reflects the way politicians and political parties think in the United Kingdom, ad which narratives in North Cyprus they have selected to represent and take on as their own, reminding us of Schudsons (2003), that all 
representations are selective.

The actions of the Turks in the 1974 developments were presented as almost barbaric. The reason for this representation of the Turks and Turkey maybe because they have continually prevented the British agenda (Bartlett, 2013) in relation to Cyprus, which would have been especially apparent during this notably active political period. As asserted by White Mythology, developments are evaluated from the white western male perspective, however, what can be said is that Turkey's position in the Cyprus problem is uninvited, possibly due to the obstruction and difficulties they have displayed towards the three European countries involved: Greece, South Cyprus, and the United Kingdom, all part of the occident, all part of the Self. This form of representation is more notable and relevant in contrast with the forms of representations of the other identities involved.

A further method of orientalising the Turk, this time the identity of the Turk being grouped (Jackson, 1996), both the Turkish Cypriots and the Turks into one representation in a totalizing dialectic typical of othering, the 'Turk' was represented by highlighting what they are not. In an article in relation to the attempts for resolution before the South of Cyprus was set to join the EU, The Guardian journalist Michael Theodoulou stated "culturally and historically the Greek Cypriots feel European. But their motivation in joining the EU is overwhelmingly political: being part of the bloc would remove the fear of further Turkish expansionism" (1 October 2001). The referral to the Eurocentric "bloc" in which the Turkish Cypriot identity was not associated with at the time, is a showcase of the position of the Turkish Cypriot and the Greek Cypriots on the self-other axis, years prior to this ideology becoming reality when the Greek Cypriots were admitted to the EU on 1 May 2004. This method of implementing orientalism is typical in defining the 'self' while simultaneously defining the 'other' in a display as to what they are not. As mentioned by Pickering (2001): "The Other is always constructed as an object for the benefit of the subject who stands in need of an Objectified Other in order to achieve a masterly self-definition" (p.71).

In terms of the level of challenging the British agenda, next in line in the hierarchal form of othering were the Turkish Cypriots, who were not evaluated as being orientalized in the classic notion as presented by Said (2003) but were othered throughout the articles. Previously seen and documented orientalist words used in the representation of Turkey and the Turks, such as "Islamic", "Muslim", and "exotic", were not generally found to be used in the case of the Turkish Cypriots. Orientalism, however, 
was not all together non-existent in the case of the Turkish Cypriots. Offensive words such as "kebab posting" (The Times, 25 February 2003) or referral to the sound of a minaret to the north of the island, when no religious affiliations were mentioned to the south, reminding us of Devran's (2007) assertion that whenever Turkey (or the Turk is mentioned in this case), space is given to highlight their Islamic identity, and as the Islamic faith already has negative connotations connected to it (Douai and Lauricella 2014), such unnecessary mentions immediately frame negative images in the mind of the reader; "on the Greek side, we can hear the Muslim call to prayer in strange exchange" (The Guardian, 1 March 2002). Othering was established instead with frequent comparisons with the Greek Cypriots, with the Turkish Cypriots projected as lesser than the Greek Cypriots often, by referring to their underdeveloped and static nature in every sense possible within a society, their inferior economy, and their problematic political status emphasized frequently. Take these excerpts from the Guardian: "[After 1974] while most Greek Cypriots had to make do with humble refugee homes, their Turkish compatriots were invariably housed in vacated villas" (20 November 2003). Or this one: "The Turkish Cypriots - whose income is roughly seven times lower than the Greek Cypriots - have historically opposed the right of return, on the grounds that they would be outbought and outnumbered" (Guardian, 12 November 2002). Some extracts treat Turkish Cypriots as if they are "mainland Turks": "Greek to the south, Turkish to the north; the one cosmopolitan, the other underdeveloped" (17 July 1999), or this one: "The Greeks need the workers the Turks can provide. The Turks need that work, access for their goods in southern Cyprus, and, above all, access to the EU, which Greek Cyprus will join next May” (Guardian, 9 May 2003). Such examples were observed in the Guardian, an influential daily British newspaper where its readership is generally on the mainstream left of the British political spectrum: "So Northern Cyprus continues to forge its path. Economic embargoes mean it is far less wealthy than the Greek Cypriot South, and desperately dependent on financial aid from the Turkish mainland" (Guardian, 1 July 2000). In further examples from the Guardian, "[In the North of Cyprus] there are no body-piercing parlours or Body Shops here, just piles of cheap Chinese products and fake Calvin Klein jeans" (17 July 1999). In a comparative paragraph between Lellos Demetriades and Semi Bora, the mayors of Nicosia to the south and the north at that period of time, it was speculated: "Demetriades was expecting visits from the president of the Belgian parliament and the ambassador from Greece, and due to attend a reception for a new Bulgarian professor at the University of Cyprus (south). When I met Bora, he was knawing his nails at an empty desk in front of an empty diary, with just my name on it" (The Guardian, 17 July 1999). In the above derogatory manner in which the two mayors are compared and positioned, the mayor in the south is portrayed as an important person, dealing with important issues and people (e.g., "president", "ambassador" or "professor"), while the mayor to the north is portrayed as unimportant, "knawing his nails" "at an empty desk", and an "empty diary". Such content may frame images that the Greek Cypriot politicians are better 
positioned in comparison to their compatriots while establishing a view in the reader that the Turkish Cypriots are less in IQ, primitive, and under-established. The same example went on to compare each side of the divided city of Nicosia, "To the north, the buildings were older, shabbier, shorter. The Saray towered above them all. To the south, the walled city was ringed by buildings that were even higher than the Saray. There was a clear financial district. There were signs of wealth in the scale of the buildings. The cars shone brighter, newer, and there were more of them moving along the wider streets (The Guardian, 17 July 1999). These examples incorporate derogatory content concerning the Turkish Cypriot community, projecting them as economically poorer than the Greek Cypriots, questioning how pertinent such descriptions are in relation to such an important ethical issue, and how ethical it is to give space to them.

The Turkish Cypriot orientalism was also interpreted as less than that of Turkey, due to the fact that often they were projected as victims to Turkey's interventions and presence, and subordinate to this nation: "Turks dismiss Cyprus talks" (Guardian, 25 November 2000). The same Sunday Times article mentioned previously, also exposes evidence of both traditional forms of orientalism in the representation of the Turks and the projection of the Turkish Cypriots as victims at the hands of Turkey's agenda, it was speculated: "Denktash [former representative of the Turkish Cypriots] has encouraged mainland Turks to settle there [in Cyprus], most of them from underdeveloped eastern Anatolia. The women wear Islamic dress and have large families. Turkish Cypriots, who are mostly secular, have become a minority within their own "republic"' (17 November 2002). Not only is this another example of the orientalist ideology being applied to Turks, as noted earlier, but it is being suggested that by enabling Turkish citizens to emigrate to Cyprus, from particular parts of Turkey (e.g., "Anatolia") where the society is a better fit of the orientalist description, this content indicates that Turkey does not care for the autonomy of the Turkish Cypriot state or their welfare and is only concerned with their particular agenda on the island. Another example of such is the excerpt from the Guardian, 1 July 2000, presented earlier, "[Northern Cyprus are] desperately dependent on financial aid from the Turkish mainland". With the word 'isolation' being mentioned in total 37 times across the 45 articles, this excerpt is another example, "it would bring to an end the international isolation of Northern Cyprus, which is recognised only by Turkey" (The Times, 1 October 2002).

It was analysed that the Greek Cypriots were rarely othered or represented with a derogatory tone. The interesting finding observed in connection to this nation of people, who are generally known to be part of the Self, is that any form of negative content with relation to the Greek Cypriots was made within articles reporting on Greek Cypriot challenges upon the British authorities on the island. Such defensive 
in tone articles was accusatory towards the Greek Cypriots while defending the British presence: "It really hurts to have a divided island, and it's easier to blame the British more than anybody else" (Independent, 5 July 2001). At any other time, the Greek Cypriots were hardly referred to in a derogatory manner. While this finding is not othering in the same sense of the Turks, with no orientalism observed in the traditional sense, as presented by Said (2003), the article is highlighting the unideal political situation the Greek Cypriots are experiencing, displaying it as a weakness, while attributing a child-like manner and tone to the actions of the Greek Cypriots. The tone suggested in the article is that the Greek Cypriots are acting irrationally and their actions unjustified, using the Cyprus problem against the Greek Cypriots in this sense, while defending the British problem upon the island. The use of such a sentence is questionable in objective journalism, and from an ethical perspective. It cannot be ignored that an identity attributed to that of the 'self' has been subjected to a derogatory representation, and it also cannot be ignored that this form of representation only existed with articles where the Greek Cypriots were challenging the British. Such a finding indicates a different level of significance when evaluated with the rest of the findings, in the sense that there is a theme with relation to the level of inconveniencing the British agenda with relation to the island of Cyprus.

Finally, and interestingly, often the British identity had their role and positions glorified, with any misdemeanours imposed by the British presence and their army downplayed, trivialized, and even joked about. An example of this was seen in the Guardian; "The two sovereign bases have provoked little controversy since they were negotiated at the time of Cypriot independence in 1960 - barring embarrassing incidents involving drunken troops" (5 July 2001). The Independent also engaged in downplaying and trivializing the negative actions of the British presence; "But middle England transplanted to the Med is not quite so ideal for single soldiers, whose need for the company of the opposite sex can run counter to the similar needs of local youth. Competition for the favours of female tourists, fuelled by duty-free alcohol, can erupt into violence” (5 July 2001).

\subsection{Investment in White Mythology}

Across the 45 articles analysed, 39 can be deemed as investing in white mythology. In terms of news texts, it is possible to engage in white mythology not only with what is stated and shared in information but also with what is not. In this case, as well as the further findings stated below, it was found that across the 45 articles, 6 were feature articles. Of these 6 feature articles, 5 were in-depth and lengthy pieces that told the Greek Cypriot perspective only, while the one remaining article provided a more balanced view. 
The white mythology ideology was assessed as being applied in two distinct ways by the British press. The first way in which white mythology was observed was concerning the subject of the actions taken by Turkey in 1974. Of the 45 articles, 27 (13 of which in the Guardian and six in the Independent) articles referred to this intervention as an "invasion" or "occupation", with these words (and variations of them) being used a total of 54 times. Take this example from the Independent: "Turkey is the only country that recognizes the self-declared Turkish Republic of Northern Cyprus. It has kept some 30,000 troops on the island since it invaded in 1974 in response to a Greek Cypriot coup backed by Athens" (13 November 2002). And this one from the Daily Telegraph: "Since the Turkish army invaded Northern Cyprus in 1974..." (3 January 2003). Or this one from the Guardian: "The Turkish invasion of the island in 1974 rescued Turkish Cypriots from their often-embattled enclaves but only to concentrate them in a larger territory that was physically more secure but, because unrecognized and entirely dependent on mainland Turkey, almost as isolated" (9 May 2003), and this one; "Ultra-nationalists bent on union with Greece toppled Archbishop Makarios, the Greek Cypriot president. This gave Turkey every excuse to invade in the name of the Turkish Cypriot minority it was pledged to protect" (The Guardian, 13 February 2002). Across these examples and the last one especially, while the events and atrocities regarding the Greek Military Junta Coup d'état in 1974 have been missed detrimentally and fundamentally to the understanding of the reader, the actions of Turkey which ultimately saved the Turkish Cypriots from genocide, as well as atrocities against the Greek Cypriots who were also seen to suffer at the hands of the guarantor country Greece, all but ignored by guarantor country the United Kingdom, were reduced to an excuse to invade by the British press. Kauffman (2007), however, argued, "The partition occurred so quickly after the July 1974 coup by Greek Cypriot ultra-nationalists that was the main source of the fear of very large-scale ethnic cleansing that we cannot know what the new government might have done. What we can confidently say is that absent partition, deadly communal violence in Cyprus would have continued to recur and that there are grounds, including the behaviour of the July coup regime, for guessing that the ultimate cost would more likely have been higher rather than lower than that of partition (p.1). With the frequent use of the word "invasion" and a constant reference to the Turkish military stationed on the island, an image of Turkish soldiers lining the streets is established by the British press. Enhancing this imagery is the constant referral to the number of Turkish soldiers present in Cyprus, numbers they fail to present about any British, UN, or Greek military presence. As with the above interpretation of the finding has asserted, the frequent description of Turkey's intervention in 1974 as being an "invasion", is asserting the illegal actions of this country, thus presenting a notion of them being barbaric and primitive nation. To appropriate such a label to this event with no background information to accompany it represents the actions of Turkey in relation to this development as irrational, extreme, and unlawful; all labels that Turkey has previously been seen to be Orientalized with. Of the 27 articles, 
14 articles, did not provide any background information, which might mean that there has been little attempt to understand the 'other's' perspectives in the British press. This can also be particularly noted in the fact that of the 45 articles analysed, 6 were in-depth feature articles, with 5 of them in relation to the Greek Cypriot perspective of the Cyprus problem, and one of them providing a more balanced outlook on the issue. While the international community, including the UN, has accepted the actions of Turkey as invasion, there is, another perspective to this story held by the Turkish community, and it is not for the journalist to take the side of the dominant view but to ethically present the facts to the reader, allowing them to decide. Such an ethical issue can be found in the following article from the Independent, which presented the actions of 1974 as unnecessary, extreme, unprovoked, and potentially barbaric, a word likened to the Turks previously: "When I served there [Cyprus] in 1974 during the Turkish invasion, the Greek Cypriots were chucked out of the northern half of the island” (The Independent, 5 July 2001). The result of this standalone comment with no background information to accompany would lead a reader who does not know the developments in Cyprus some 27 years prior, that there was not Greek Military Junta Coup d'état, that the elected government in the RoC had not been toppled, with an assassination attempt on the Greek Cypriot President, and that British, Greek Cypriot and Turkish Cypriot lives alike were not in danger, with plans of genocide upon the Turkish Cypriot community. The result of this white mythology, as the rest of the world seems to understand the events to have developed, may have led to the idea that the current plight of the Turkish Cypriots is justified. This notion has already been used against Turkey in international politics, and specifically in their bid to join the EU since 1987.

As a second effort of the White Mythology ideology, and to eradicate any notion of wrongdoings on behalf of the British presence on the island, no background information was provided noting the previous harmonious living between the two communities present on the island (Varnava 2009), before the British colonization. This lack of information aside, the British role of peacemaker has been given mention when possible; "Britain offers to scale down bases for Cyprus peace" (Times, 25 February 2003) and The Daily Telegraph's article “Army land may be lost in Cyprus peace plan” (25 February 2003), outlining the offer made by Britain to return 45 square miles of sovereign base land, which is not required by the British military, to aid reconciliation. Such content can also be viewed in two other articles "Why a corner of the island remains forever Britain (The Guardian, 5 July 2001) and "Defence: A divided island where the living seems to be easy" (The Independent, 5 July 2001) where the sole subject was to justify the sovereign bases about the Cyprus issue, following violence from Greek Cypriots in reaction to an antenna to be erected at the Akrotiri RAF station. As a result, in the few articles that handle their presence on the island and to justify the British military soil in Cyprus, emphasising their strategic importance, 
narratives can be located that will refer to being placed in a "crisis-ridden part of the world" (The Guardian, 5 July 2001) and "in a part of Europe that is frighteningly close to unravelling" (The Independent, 5 July 2001). Such narratives raise sympathy in the reader for the sacrificial position the British military play in dealing with world security matters. What is missing throughout is without compunction, the pivotal role played by the British in the establishment of the Cyprus issue. This finding of white mythology is typical in Robert C. Young's (1990) understanding of what white mythology is. Britain's representation of the events and their role appears to be Eurocentric, presenting themselves as more modern and in control, thus more powerful in relation to the Turkish Cypriots, and even in some aspects above the Greek Cypriots also. What else this finding can be interpreted as is ignoring how the presence of a British base has received much negative response, from mainly the Greek Cypriots, their presence in Cyprus often questioned as no necessity in relation to the Cyprus problem. This is part of the very definition of white mythology, another tool to set themselves above the rest in their Eurocentric ideology. This is something that has been viewed and noted throughout western colonial history, and it seems to be no different in this case either.

\section{CONCLUSIONS}

This article offers important insights into how Turkey is represented in the British news texts covering the Cyprus problem. The study asked, how were Turkish people portrayed by the British press in news about the Cyprus problem? It lays down that Said's (2003) orientalism was present within the news texts produced by the British press during the 2000s and in relation to the Turks in particular. Turkish people from Turkey were represented with words referring to Islam, headscarf, skin colour, and as being settlers and land invaders, while derogatory narratives were formed in relation to their socioeconomic standings. By constructing Turks as backward, an axis is established placing them in the category of the "other". The study did not find any significant differences in coverage between different newspapers; their reporting was almost uniform. What is a defining moment, untypical from the traditional notions of orientalism, is that a community or nation that would normally be accepted within the "self" with no exception, due to their upholding of the qualities and characteristics of the self (white, Western and non-Muslim), was othered, not because of their location as further south and east in Europe; as per Milica Bakić-Hayden's nesting orientalism (1995), but because of their role in obstructing and inconveniencing a former imperial nations ideals and agenda. As far as we are concerned, this type of representation has never been observed, in the form of hierarchal orientalism or changeable hierarchy of representations, based on the ethnic, religious, and cultural characteristics of those being othered, but 
also their position with regards to their current position or actions affecting the ideals or agenda of the United Kingdom, in this case. This finding echoes Gitlin's (1980: 28) notion that "an opposition movement is ordinarily, routinely and unthinkably treated as a sort of crime". Creating such an enemy image is typical and beneficial, which is a reinforcement of "ancient ideological dichotomies of good versus evil and us versus them" (Merskin 2004: 158), which solidifies consensual stereotypes, beneficial for the orientalist ideology. The image of this enemy culturally influences "very negative and stereotyped evaluation of the "other"' (Fiebig-Von Hase 1997: 2). Reinvestment of this ideology is characteristic of classic orientalism (Said 2003), in the reinforcement of political power, and the definition of the applicator's identity, and particularly in defence of the power in the question of political and economic interests. Such an interpretation is supported by Schudson (2003), who states that journalists often feel the obligation of representing news in light of the security and preservation of their country.

The orientalism interlaced within the texts of the British news articles evaluated displayed a hierarchy among those identities referenced, with the conditions of this hierarchy depending on two factors; firstly, those typically identified and accepted as the "self", by maintaining the characteristics of such a privileged status, and secondly, concerning their position with regards to the British position and agenda, upon the island of Cyprus. While the Greek Cypriots were predominantly treated and represented as part of the "self" within the news articles, their status altered, and their hierarchal position decreased when the Greek Cypriots imposed difficulties upon and challenged the British agenda.

With relation to the difference in the orientalism applied upon the Turks and Turkish Cypriots, from an orientalist perspective, it can be concluded that the characteristics and qualities carried by these two nations of people are not that different. In other words, they both identify as Muslim, and as part of the East and are not classed as white as Europeans. The difference, in this case, can be interpreted as their positions in relation to the British agenda, which was understood by the narrative present within some of the news texts. Turkey was displayed and projected as inconveniencing the Turkish Cypriots, hindering the political development of the Turkish Cypriots and Northern Cyprus, while the Turkish Cypriots were positioned as victims of the Turkish agenda. In comparison to the other role-holders present within the Cyprus problem, Turkey was seen to be traditionally Orientalized, presented as barbaric, unsecular, underdeveloped, and defiant in the face of the western powers, their inferior representation displaying them as audacious for such actions. By so doing, and as Cirakli (2018) has found out, Turkish migrants were constructed as a threat to the political will of the Turkish Cypriot community. Where no descriptive content was necessary and not applied to the other role holders in this conundrum, the Islamic faith of 
the Turks received frequent mention, their skin colour, their clothing, number of children, and even the fact that they kept chickens.

The White Mythology present within the articles was established in two different areas. Firstly, in a manner where it painted the Turks and Turkish Cypriots in a negative light, and secondly, where it glorified the British presence upon the island, interpreted as in favour of the British agenda in Cyprus, and beneficial to the Greeks and Greek Cypriots. By omitting background information concerning the Cyprus problem, the British press, it could be argued, was successful in othering the Turks and Turkish Cypriots in two ways. Firstly, the lack of information represented the actions of Turkey in a negative light. Secondly, the news articles are arguably successful in othering the Turks and the Turkish Cypriots by establishing a version of events in the minds of the readership that were not the full version of events, and an understanding that was not favourable for either of these states. We know from the literature that, “The U.K. press is highly partisan" (Walter 2019: 211). Especially national newspapers "are highly opinionated, pick sides and push agendas; they are powerful and overt political players, willing and at times apparently able to shape the agendas" (Scammell and Semetko 2008: 74). News outlets that vilify Turks are likely to have devoted more coverage to this aspect, while background information is kept minimal or not given space at all. Such negative stories about the others can catch and keep the readers' attention.

Finally, the British were established as highest in this self-other hierarchy, with the trivializing and downplaying of any British misdemeanours, by the defensive and judgmental tones against the Greek Cypriots, orientalising them with accusations of irrational behaviour when they were inconveniencing the British agenda, and by the peacemaker role they were presented with. Our results provide empirical confirmation about how the British press represents Turkey in the news covering the Cyprus problem. But a true understanding of othering can be achieved by exploring further how other role players, Greece, Greek Cypriots, and Turkish Cypriots are represented in western media.

\section{REFERENCES}

Aissaoui, Rabah. 2007. History, Cultural identity and difference: The issue of Turkey's accession to the European Union in the French national press. Journal of Southern Europe and the Balkans 9(1): 1-14. 
Bail, Chris A. 2015. Terrified: How Anti-Islam Fringe Organisations Became Mainstream. New Jersey: Princeton University Press.

Barthes, Roland. 1961. The photographic message. In: Barthes, R. (Ed.), A Barthes Reader, 1st ed., pp. 196 - 199.

Bartlett, Margaret W. 2013. Cyprus 1960-1970: An Intellectual History of the Cold War Toll, the United Nations and Decolonisation, Ph.D. dissertation, New Jersey, Drew University.

Bakić-Hayden, Milica. 1995. Nesting orientalisms: The case of Former Yugoslavia. Slavic Review 54(4): 917-931.

Birce, Bora. 2015. Representation of Turkey in the British Print Media: To Be or Not To Be European. Ph.D. dissertation, London, City University London.

Bryce, Derek. 2007. Repackaging orientalism: Discourse on Egypt and Turkey in British outbound tourism. Tourist Studies 7(2): 165-191.

Burr, Vivien. 1995. An Introduction to Social Constructionism. London: Routledge.

Chomsky, Noam, Herman, Edward, S., 1988. Manufacturing Consent: The Political Economy of the Mass Media. New York: Pantheon Books.

Cirakli, Mustafa (2018). Turkish migration into the north of Cyprus and the (re)construction of Turkish Cypriot identity in the Turkish Cypriot press (1995-2013). In Kyritsi, Thekla and Christofis, Nikos (Eds.), Cypriot Nationalisms in Context: History, Identity and Politics. Palgrave Macmillan, pp. 199-219.

Devran, Yusuf. 2007. The portrayal of Turkey in the British media: Orientalism resurfaced. Insight Turkey 9(4), $100-115$.

Douai, Aziz, and Lauricella, Sharon. 2014. The ‘terrorism' frame in 'neo-orientalism': Western news and the SunniShia Muslim sectarian relations after 9/11'. International Journal of Media \& Cultural Politics 10(1): 7-24.

Fiebig-von Hase, Ragnhild. 1997. Introduction. In: Fiebig-von Has, R., Lehmkuhl, U. (Eds), Enemy Images in American History. Berghahn Books, pp. 1-42.

Fourie, Pieter J. 2001. Media Studies: Content, Audiences and Production. South Africa: Juta and Company Ltd.

Fowler, Roger. 1991. Language in the News: Discourse and Ideology in the Press. London: Routledge.

French, David. 2016. Fighting EOKA: The British Counter-Insurgency Campaign on Cyprus, 1955-1959. Oxford: 
Oxford University Press.

Gangloff, Sylvie. 2008. Turkey's accession to the EU: The flexible reality underlining the debate. In: Timmerman, C., Rochtus, D., Mels, S. (Eds.), European and Turkish Voices in Favour and Against Turkish Accession to the EU. PIE Peter Lang, pp. 33-44.

Gans, Herbert J. 1979. Deciding what's news: Story suitability. Society 16: 65-77.

Gitlin, Todd. 1980. The Whole World is Watching: Mass Media in the Making and Unmaking of the New Left. Berkeley: University of California Press.

Göktürk, Turgay B. 2018. Türkiye’nin 1974 öncesi Kıbrıs Politikası, vizyonu ve uygulamaları. Okman Printing Ltd.

Hall, Stuart. 1997. The spectacle of the "Other". In: Hall, S. (Ed.), Representation: Cultural Representations and Signifying Practices. London: Sage, pp. 223-279.

Herman, Edward S., and Chomsky, Noam. 2002. Manufacturing Consent: The Political Economy of the Mass Media. New York: Pantheon Books.

Jackson, Nancy B. 2003. Arab Americans: Middle East conflicts hit home. In: Lester, P.M., Ross, S.D. (Eds), Images That Injure: Pictorial Stereotypes in the Media. Westport, CT: Praeger, pp. 75-83.

Kauffman, Chaim. 2007. An assessment of the partition of Cyprus. International Studies Perspectives, 8(2): 206223.

Kliot, Nurit, and Mansfield, Yoel. 1997. The political landscape of partition: The case of Cyprus. Political Geography 16(6): 495-521.

Kösebalaban, Hasan. 2007. The permanent “Other"? Turkey and the question of European identity. Mediterranean Quarterly 18(4): 87-111.

Kylstad, Ingrid. 2010. Turkey and the EU: A 'new' European identity in the making?'. LEQS Paper No: 27. Available at https://ssrn.com/abstract $=1708025$

Lévi-Strauss, Claude. 1963. Structural Anthropology. New York: Basic Books. Van Dijk, T., 1991. Racism and the Press. Routledge. 
Van Dijk, Teun. 1993. Principles of critical discourse analysis. Discourse \& Society 4(2): 249-283.

Manoff, Robert K, and Schudson, Michael. 1986. Reading the news. In: Manoff, R.K., Schudson, M. (Eds.), Reading the News: A Pantheon Guide to Popular Culture. New York: Pantheon Books, pp. 1-8.

Merskin, Debra. 2001. Winnebagos, Cherokees, Apaches, and Dakotas: The persistence of stereotyping of American Indians in American advertising brands. Howard Journal of Communication 12(3): 159-169.

Merskin, Debra. 2004. The construction of Arabs as enemies: Post-September 11 discourse of George W. Bush. Mass Communication \& Society 7(2): 157-175.

McNair, Brian. 2009. News and Journalism in the UK. London: Routledge.

Navaro-Yashin, Yael. 2006. De-ethnicizing the ethnography of Cyprus: Political and social conflict between Turkish-Cypriots and settlers from Turkey. In: Papadakis, Y., Peristianis, N., Welz, G. (Eds.), Divided Cyprus: Modernity and an Island in Conflict. Bloomington: Indiana University Press, pp. 84-99.

Negrine, Ralph., Kejanlioglu, Beybin., Aissaoui, Rabah, and Sylianos Papathanassopoulos. 2008. Turkey and the European Union: An analysis of how the press in four countries covered Turkey's bid for accession in 2004. European Journal of Communication 23(1): 47-68.

Press.

Neumann, Iver B. 1999. Uses of the Other: "The East" in European Identity Formation. University of Minnesota

Nossek, Hillel. 2004. Our news and their news: The role of national identity in the coverage of foreign news. Journalism 5(3): 343-368.

Paksoy, Alaaddin. F. 2012. Representation of Turkey’s EU Bid in the British media. PhD dissertation, Sheffield, University of Sheffield.

Pinkus, Jenny. 1996. Subjects Positions and Positioning. Available at http://www.massey.ac.nz/ alock/theory/subpos.html14

Poole, Elizabeth. 2002. Reporting Islam: Media Representations of British Muslims. London: I.B. Tauris.

Poole, Elizabeth., Richardson, John E. 2006. Muslims and the News Media. I.B. Tauris.

Psaltis, Charis., Cakal, Huseyin. 2016. Social identity in divided Cyprus. In McKeown, S. et al. (Eds), Understanding Peace and Conflict Through Social Identity Theory. New York: Springer, pp.229-244. 
Saeed, Amir. 2007. Media, racism and Islamophobia: The representation of Islam and Muslims in the media. Sociology Compass 1(2): 443-462.

Said, Edward. 2003. Orientalism: Western Conceptions of the Orient. Routledge.

Saussure, Ferdinand.de. 2011. Course in General Linguistics. Translated by W. Baskin. Edited by P. Meisel and H. Saussy. New York: Columbia University Press.

Scammell, Margaret., Semetko, Holli A. 2008. Election news coverage in the U.K. In: Strömbäck J. and Kaid L.L. (Eds.) The Handbook of Election News Coverage Around the World. London: Routledge, pp. 73-89.

Schreier, Margrit. 2012. Qualitative Content Analysis in Practice. London: Sage.

Schudson, Michael, 2003. The Sociology of News. New York: W.W. Norton.

Sözen, Ahmet., Özersay, Kudret. 2007. The Annan plan: State succession or continuity. Middle Eastern Studies 43(1): 125-141.

Spivak, Gayatri, C., 2009. Can the subaltern speak? In Sharp, J.P., (Ed.), Geographies of Postcolonialism: Spaces of Power and Representation. Sage, pp. 109-130.

Spyrou, Spyros. 2002. Images of the "Other": "The Turk" in Greek Cypriot children's imaginations. Race Ethnicity and Education 5(3): 255-272.

Şahin, Sanem., Karayianni, Christiana 2020. Journalism matters: Reporting peace in Cyprus. Media, Culture \& Society 42(7-8): 1360-1376.

Varnava, Andrekos. 2009. British Imperialism in Cyprus, 1878-1915: The Inconsequential Possession. Manchester University Press.

Walter, S. 2019. Better off without you? How the British media portrayed EU citizens in Brexit news. The International Journal of Press/Politics 24(2): 210-232.

Wimmel, Andreas. 2009. Beyond the Bosporus? Comparing public discourses on Turkey's EU application in the German, French and British quality press. Journal of Language and Politics 8(2): 223-243.

Xydis, Stephen, G. 1973. Cyprus: Reluctant Republic. Berlin: De Gruyter Mouton.

Young, Robert. J.C. 1990. White Mythologies: Writing History and the West. Routledge. 
APPENDIX 1: List of news items used for analysis

1. The Guardian. 1999. "Passing years harden island rift." July 07, p.15.

2. The Guardian. 1999. "Split for infinity?” July 17, p.20.

3. The Guardian. 2000. "Divided Village damps hope for Cyprus unity.” July 01, p.1 and 17.

4. The Guardian. 2000. "Turks dismiss Cyprus Talks.” November 25, p.1 and 18.

5. The Guardian. 2001. "Why a corner of the island remains forever Britain.” July 05, p.1 and 3

6. The Independent. 2001. "Defense: A divided island where the living seems to be easy." July 05, p.3

7. The Times. 2001. "Just a whisker away from unity." October 01, p.18.

8. The Independent. 2001. “Cypriots will meet for talks on unification.” December 05, p.16.

9. The Times. 2001. "Cypriot leaders meet in Turkish north.” December 05, p.2.

10. The Daily Telegraph. "'Dinner diplomacy on divided island Leaders' meeting lifts hopes of Cyprus deal.” December 05, p.19.

11. The Guardian. 2002. Island of division: Time to get it together over Cyprus. January 16, p.1 and 19.

12. The Daily Telegraph. 2002. "Fresh hope as Cypriot leaders begin talks.” January 17, p.13. 
13. The Guardian. 2002. "Turks and Greeks break ice.” February 13, p.1 and 17.

14. The Guardian. 2002. "Cypriots dare to dream of a united future: Talks between island leaders raise hopes of reconciliation.” February 13, p1 and 17.

15. The Guardian. 2002. "Divided they stand.” March 01, p.2.

16. The Daily Telegraph. "Turkish Cypriots leave island as 'settlers' move in.” September 07, p.24.

17. The Times. 2002. "Unity lies in their hands." October 01, p.34.

18. The Guardian. 2002. "UN sets deadline for Cyprus deal.” November 12, p.1 and 15.

19. The Independent. 2002. "Winner of Turkish elections backs efforts to reunify Cyprus." November 13, p.12.

20. Sunday Times. 2002. "Greeks who lost homes fight Cyprus deal.” November 17, p.26.

21. The Independent. 2002. "Letter: Cyprus Refugees.” November 26, p.21.

22. The Independent. 2002. "Minister predicts Cyprus solution by February.” December 1, p.10.

23. The Times. 2003. "Erdogan presses for deal over Cyprus.” January 03, p. 14.

24. The Daily Telegraph. 2003. "Turkey warns its hardline Cypriot allies.” January 03, p.15.

25. The Independent. 2003. “Turkey must negotiate on Cyprus, says news leader.” January 03, p.10.

26. The Independent. 2003. “Athens accepts UN invitation to Cyprus talks.” February 07, p.11. 
27. The Guardian. 2003. "Election holds key to peace in Cyprus." February 15, p.1 and 18.

28. The Daily Telegraph. 2003. "Defeat for Clerides clouds Cyprus deal." February 17, p.12.

29. The Independent. 2003. "Time is short for the divided people of Cyprus." February 18, p.14.

30. The Daily Telegraph. 2003. "Army land may be lost in Cyprus peace plan.” February 25. p.13.

31. The Times. 2003. "Britain offers to scale down bases for Cyprus peace." February 25, p.15.

32. The Independent. 2003. "UN hands choice on unity to Cypriots." March 11, p.11.

33. The Guardian. 2003. "Jubilant Cypriots cross divide.” April 23, p.1 and 16.

34. The Guardian. 2003. "Free movement may still heal the division of Cyprus." May 09, p.1 and 24.

35. The Guardian. 2003. "Turkey and Greece talk peace." October 22, p.18.

36. The Independent. 2003. "Mehmet Ali Akpinar; Turkish Cypriot journalist who sustained his objectivity." October 31, p.22.

37. The Times. 2003. "Cyprus impasse thwarts entry to European club.” November 06, p.18.

38. The Guardian. 2003. "Property holds key to progress on divided island." November 20, p.1 and 17.

39. The Guardian. 2003. "Turkey agrees to pay Greek Cypriot compensation for house seized in 1974." November 20, p.1 and 17. 
40. The Guardian. 2004. “Cyprus: Turkey’s pivotal role.” January 12. p.17.

41. The Guardian. 2004. "Denktas puts Cypriot deal back into play." January 13, p.14.

42. The Guardian. 2004. "Turkish generals back talks on Cyprus.” January 24, p.12.

43. The Guardian. 2004. "Bomb aimed at Turkish leader as Cypriot talks begin." February 20, p.13.

44. The Guardian. 2004. "Cyprus hopes look dim.” March 26, p.15.

45. The Times. 2004. "Last chance for Cyprus." March 29, p.19

\section{EXTENDED ABSTRACT}

This paper presents the presence of othering in relation to Turkey and its people in the 2000s. This article will provide insights into how foreign others are represented in British daily newspapers, made more significant when the Cyprus problem is concerned. The Cyprus problem is a long-standing conflict between two ethnic communities: the Turkish and Greek Cypriots, and as the literature has previously indicated and crucial to this study, a conflict between the self and the other, upon a small Mediterranean Island. In particular, the study aims to understand the complexity of the representation of the Turkish identity among and in comparison, to the other role-playing identities within the Cyprus problem. Given Turkey is one of the role-playing states in the fate of Cyprus and has required political control over the northern part of Cyprus, to ensure the safety of the Turkish Cypriot population (Bartlett 2013), as it is claimed, or as another land to conquer and rule over, as some may argue, it's a case par excellence to evaluate how the British press represents Turkey as a second signatory to the Treaty of Guarantee; a treaty between Cyprus, Turkey, Greece, and the United Kingdom. Primarily relying on the theoretical work of Said's Orientalism (2003) and Young's (1990) White Mythology, and by applying a qualitative content analysis (Schreier 2012) upon 45 news articles that take the Cyprus problem to hand as the core subject, and are published across five British broadsheet newspapers (The Guardian, The Times, The Sunday Times, The Independent, and The Daily Telegraph), this study aims to uncover the following two questions: How is Turkey represented in the news content of British daily newspapers covering the 
Cyprus problem from 1999-2004? What kind of language is dominant in portraying the Turkish people politically, economically, and culturally, in the selected period?

The findings establish that the British press portrayed Turkish people involved in the Cyprus problem as "dark-skinned Turks", "from underdeveloped eastern Anatolia" that "wear Islamic dress" and are "settlers" or occupiers on the Cyprus island. The Turkish Cypriots were held differently from the Turkish nationals, who were orientalised in the traditional sense. Turkish Cypriots were othered mostly in relation to the economic and political situation of Northern Cyprus. The Greek Cypriots, who uphold all the characteristics to be part of the self, were othered in the news texts only when they inconvenienced the British agenda in Cyprus. The most striking conclusion of this paper is that the level of othering runs parallel to the level of inconveniencing the British agenda with relation to Cyprus. The most derogatory content in relation to any of the role players in the Cyprus issue was attributed to Turkey, deemed as challenging the British agenda the most, followed by the Turkish Cypriots. Any derogatory content in relation to the Greek Cypriots was only noted when they were protesting British related decisions. The British, on the other hand, were glorified, and any of their misdemeanours downplayed and trivialised. Finally, the British were established as highest in this self-other hierarchy, with the trivializing and downplaying of any British misdemeanours, by the defensive and judgmental tones against the Greek Cypriots, orientalising them with accusations of irrational behaviour when they were inconveniencing the British agenda, and by the peacemaker role they were presented with. 